\title{
AUTOMATIC FACIAL REDNESS DETECTION ON FACE SKIN IMAGE
}

\author{
IzZati MUhimMaH", NuRUl FATIKaH MUChlis \\ AND ARRIE KURNIAWARDHANI
}

\author{
Department of Informatics, Universitas Islam Indonesia, Yogyakarta, Indonesia
}

"Corresponding author: izzati@uii.ac.id

(Received: $1^{\text {st }}$ June 2020; Accepted: $2^{\text {nd }}$ September 2020; Published on-line: $4^{\text {th }}$ January 2021)

\begin{abstract}
One facial skin problem is redness. On site examination currently relies on examination through direct observations conducted by doctors and the patient's medical history. However, some patients are reluctant to consult with a doctor because of shame or prohibitive costs. This study attempts to utilize digital image processing algorithms to analyze the patient's facial skin condition automatically, especially redness detection in the face image. The method used for detecting red objects on face skin for this research is Redness method. The output of the Redness method will be optimized by feature selection based on area, mean intensity of the RGB color space, and mean intensity of the Hue Intensity. The dataset used in this research consists of 35 facial images. The sensitivity, specificity, and accuracy are used to measure the detection performance. The performance achieved 54\%, 99.1\%, and 96.2\% for sensitivity, specificity, and accuracy, respectively, according to dermatologists. Meanwhile, according to PT. AVO personnel, the performance achieved $67.4 \%, 99.1 \%$, and $97.7 \%$, for sensitivity, specificity, and accuracy, respectively. Based on the result, the system is good enough to detect redness in facial images.
\end{abstract}

ABSTRAK: Salah satu masalah kulit wajah adalah kemerahan muka. Pemeriksaan di lokasi kini bergantung pada pemeriksaan melalui pemerhatian langsung yang dilakukan oleh doktor dan sejarah perubatan pesakit. Namun, sebilangan pesakit enggan berunding dengan doktor kerana rasa malu atau kos yang terhad. Kajian ini cuba membuat sistem pengesanan kemerahan wajah yang dapat menganalisis keadaan wajah, terutama kemerahan, melalui gambar kulit wajah. Kaedah yang digunakan untuk mengesan objek merah pada kulit wajah bagi penyelidikan ini adalah kaedah Kemerahan. Keluaran kaedah Kemerahan akan dioptimumkan dengan pemilihan ciri berdasarkan luas, intensiti min RGB, dan intensiti min Hue Intensity. Set data yang digunakan dalam penyelidikan ini terdiri daripada 35 gambar wajah. Nilai pengesahan yang digunakan adalah kepekaan, kekhususan, dan ketepatan. Hasil yang diperoleh berdasarkan pakar dermatologi masingmasing adalah 54\%, 99.1\%, dan 96.2\% untuk kepekaan, kekhususan, dan ketepatan. Sementara itu, PT. Selain itu, menurut kakitangan AVO 67.4\%, 99.1\%, dan 97.7\%, bagi kepekaan, kekhususan, dan ketepatan, masing-masing. Berdasarkan dapatan kajian ini, sistem ini cukup baik bagi mengesan kemerahan pada gambar wajah.

KEYWORDS: digital image processing; face skin; redness; redness method

\section{INTRODUCTION}

Most people experience problems with their facial skin, such as redness [1]. Redness is one of the topics that are often discussed in either health and beauty articles or online consultation of health sites. To examine skin problems, we usually see the doctor for on-site 
examination [2]. However, several patients are reluctant to consult with doctors for reasons such as fear and shame. As a result, they decide to treat their skin problem by themselves, commonly known as self-care. However, self-care can sometimes make the redness worse.

Examining facial skin redness using digital image processing is one solution [3-5]. One of the studies that has been conducted is assessment of Rosacea [4-5]. Rosacea is a skin redness problem [6]. Sainthillier et al. quantified the extent and intensity of the Rosacea using image processing and a neural network. The input images used in their study were localized in a specific area, namely the cheekbone area [4]. Furthermore, the investigator selected the zones affected by Rosacea on the image as well as the zones without signal (nonrosacea artefacts, e.g., white background). Those images were taken using a videocapillaroscope with a 50× magnification. Ledoux et al. utilized a perceptual color hit-ormiss transform for detecting Rosacea in skin image [5]. Input images used in their study were of a specific area of skin that contained Rosacea. Novin and Aarabi conducted research for skin redness analysis and pigmented skin lesions analysis [7]. This research analyzed body skin redness and the results were presented in the form of augmented reality on a smartphone. This research uses RGB color space to detect skin. Skin detection using this color space will also detect background objects that have a skin-like color and consider them to be skin as well. RGB color space is also used in the equation to find red regions in the skin. Pixels that have a red color above the threshold were set as part of the reddish object. In redness estimation a slider was provided to get a user defined threshold value.

This study attempts to utilize digital image processing algorithms to analyze the patient's facial skin condition automatically, especially redness detection. A facial redness detection is needed as early detection of skin redness conditions. It can help patients to analyze their facial skin abnormalities. In addition, in the future, the facial redness detection is expected to provide an overview of skincare products that are suitable for facial conditions.

\section{METHODS AND DATA}

\subsection{Data}

This research used secondary data obtained from the internet randomly and from beauty product companies (PT. AVO Innovation Technology). Data collected are human face images that have redness in their facial skin without certain race boundaries. The characteristics of the image used are color image, face position facing forward, and evenly distributed lighting. The dataset on this research is 35 images, two as training data and 32 as test data. The collected images are jpg, jpeg, png formats.

\subsection{Redness Face Skin}

Redness on skin can be caused by increase of hemoglobin saturation, increase in the diameter of the actual skin capillaries, or a combination of these factors [8]. Redness sometimes makes facial skin feel warm or gives a burning sensation. Redness can make a person feel unconfident with their own appearance. Redness on skin can occur due to inflammation, skin irritation, allergies, and bacteria [9].

\subsection{Redness Method}

Redness Method is feature extraction algorithm to calculate the redness value of each pixel. Eq. (1) is used to determine the redness value of each pixel [7].

$$
\text { Redness }=\max \left\{0, \frac{2 R-(G+B)}{R}\right\}^{2}
$$


where $\mathrm{R}=$ Red intensity in corresponding pixel; $\mathrm{G}=$ Green intensity in corresponding pixel; and $\mathrm{B}=$ Blue intensity in corresponding pixel.

\subsection{K-means Clustering}

Clustering is a method for dividing a set of data into groups. The clustering-based segmentation used in this research is K-Means. $\mathrm{K}$ in K-mean is the total number of clusters, which is randomly determined. K-means clustering will assign a data to a particular cluster according to the distance between the data and the centroid of the K cluster. Data will be assigned to a cluster whose centroid has the shortest distance to the data among the other cluster centroids [10].

\subsection{Gaussian Filtering}

Gaussian filtering is a pre-processing technique in digital image processing. This filter is usually used when an image has a lot of noise. Gaussian filtering reduces the noise by smoothing the image using the Gaussian principle [11]. Images smoothed using Gaussian filtering will usually change to a blurry image. A blurry image helps during the segmentation process because the intensity value of a pixel has a more uniform intensity value compared to its neighbors.

\subsection{Canny Method}

Canny method also known as Canny Edge Detection is a method in digital image processing to detect the edges of objects. Canny Edge Detection uses two thresholds so that it is possible to detect strong and weak edges [12]. Edges in digital image processing are found by representing a series of intensities in the image to a graph. If there are curves on the graph, this shows that there is a drastic change in the intensity of an image. This drastic change in intensity is marked as an edge.

\subsection{Validation}

The validation applied in this research is a Confusion Matrix with a Single Decision Threshold Method. This validation will compare the detection results performed by the system (predictive value) to the results of the diagnosis by the expert (actual value). According to Owens and Sox [13], sensitivity is used to measure the percentage of positive data that is correctly identified (both experts and systems detect the same redness object). Specificity is used to measure the percentage of negative data that is correctly identified (the system does not detect non-redness objects from candidates as redness objects). Accuracy is used to measure the percentage of the system's precision level in classifying data correctly (data that is predicted correctly by the system is divided by the total number of test data). The Confusion Matrix table can be seen in Table I.

Table 1: Confusion matrices

\begin{tabular}{cccc}
\hline & & \multicolumn{2}{c}{ Expert } \\
& & True & False \\
\hline \multirow{2}{*}{ System } & True & TP & FP \\
& False & FN & TN \\
\hline
\end{tabular}

Based on the values of True Positive (TP), False Positive (FP), True Negative (TN), and False Negative (FN) we can get the values of sensitivity, specificity, and accuracy. 
Following is the calculation for sensitivity, specificity, and accuracy which can be seen in Eq. (2), Eq. (3), and Eq. (4), respectively.

$$
\begin{aligned}
& \text { Sensitivity }=\frac{T P}{T P+F N} \\
& \text { Specificity }=\frac{T N}{T N+F P} \\
& \text { Accuracy }=\frac{T P+T N}{T P+T N+F P+F N}
\end{aligned}
$$

\subsection{Methodology}

The design of this research uses the flowchart seen in Fig. 1. The flowchart consists of four main processes. The input of the system is an RGB face image (Original Image) and the output of the system is a face image with a redness object that has been marked (Marked Image). The process consists of pre-processing (image resizing), separating face skin from the background (skin segmentation), redness object detection (feature extraction), and redness marking.

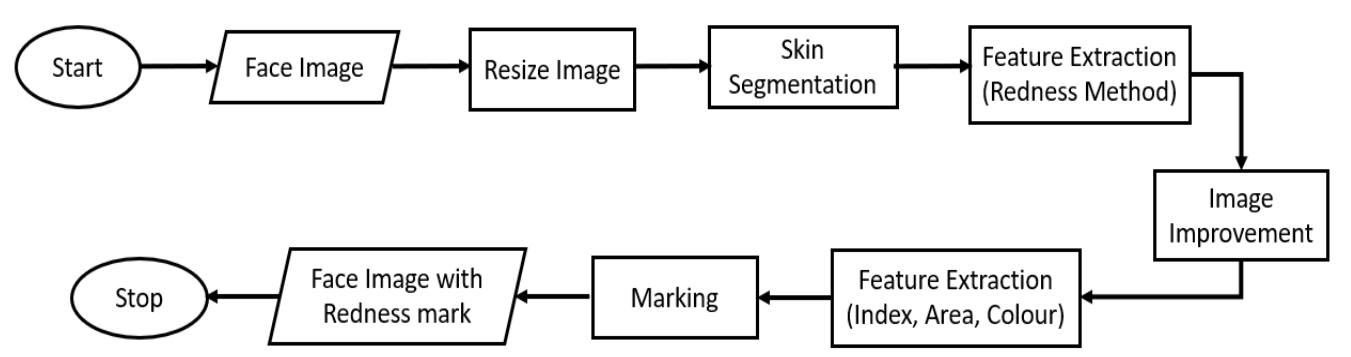

Fig. 1: Flowchart of Facial Redness Detection.

First, the input image is resized (Resized Image) when its number of rows or columns exceeds 500 pixels. If the number of rows exceeds 500 pixels and is longer than the columns, the row size will be reduced to 480 pixels and the column size will be adjusted. Conversely, if the column size exceeds the row size, then the column size will be reduced to 480 pixels and the row size will adjusted. This process is needed because the dataset used is randomly obtained from the internet so the image size can vary.

Second, skin segmentation is the process of separating skin and non-skin objects. This skin segmentation assists the redness detection process to prevent the system from detecting any redness objects that are not in the skin area. This segmentation process separates skin and non-skin objects by clustering using K-Means in the HSV color space.

The Resized Image from the Resize image process is converted to the HSV color space (HSV Image). After being converted, HSV image is segmented according to a threshold value (Segmented HSV Image). The threshold values are less than and equal to 25 for the Hue layer and between 0.15 to 0.9 for the Saturation layer. Next, the Segmented HSV Image is clustered using K-Means clustering. The number of $\mathrm{K}$ for $\mathrm{K}$-means clustering is 3, representing skin, non-skin, and background. Skin objects that will be taken from the results of K-means clustering are the cluster that has the highest number of members (Skin Image). This is done by assuming that the skin object has the broadest area in the face image.

Third, the Redness objects in the Skin Image are sought by identifying their characteristics. The Redness method [7] is utilized to calculate the redness value of each pixel in the Skin Image. The Redness method works on RGB images. First, the RGB value of each pixel in Skin Image is obtained. The redness value of each pixel is computed using 
Eq. (1). Furthermore, the median of those redness values of all pixels in an image is determined as the threshold. Each pixel that has a value lower than the median will be omitted and each pixel that has a value greater than the median will be retained as a redness object candidate. An image with a redness object candidate is obtained (Redness Candidate Image), but there is noise in that image. A Gaussian filter with standard deviation value is 0.5 is applied in that Redness Candidate Image to get a smoother image and to reduce the noise (Gauss Image).

A Gaussian Image still has non-redness objects, so the object elimination process is needed. First, non-redness objects are eliminated according to pixel value in the Gaussian Image and Redness Image. If the pixel value in the Gaussian Image is equal to 76 (indicating the Redness object in a grayscale image), the pixel value in the Redness Image is retained. Otherwise, the pixel value in the Redness Image is changed to 0 (Gaussian Redness 1 Image). Second, the pixel values in the Gaussian Redness 1 Image that are lower than 1 are retained. Otherwise, the pixel value in the Gaussian Redness 1 Image is changed to 0 (Gaussian Redness 2 Image). Third, objects in the Gaussian Redness 2 Image that have an area wider than 90 are retained. Otherwise, the object is eliminated (Area Image). Fourth, non-redness objects are eliminated by a threshold value according to the RGB color value in the Original Image. The lower threshold value for Red intensity is Mean intensity value in the Red layer subtracted by the multiplication of the standard deviation of the intensity value in the Red layer by 1.32. Whereas the upper threshold value for Red intensity is Mean intensity value in the Red layer added to the multiplication of the standard deviation of the intensity value in the Red layer by 1.32 . The same thing is done to find the lower and upper thresholds in the Blue and Green layers. If the redness object candidate in Area Image has an average intensity of RGB color in those range thresholds, the redness object candidate will be retained. Otherwise, it will be eliminated (RGB Eliminated Image). Fifth. nonredness objects are eliminated by a threshold value according to Hue color value in the Original Image. The lower threshold value for Hue intensity is Mean intensity value in the Hue layer subtracted by the multiplication of the standard deviation of the intensity value in the Hue layer by 1.16. Whereas the upper threshold value for Hue intensity is the Mean intensity value in the Hue layer added to the multiplication of the standard deviation of the intensity value in the Hue layer by 0.5 . If the redness object candidate in the RGB Eliminated Image has an average intensity of hue color in those range thresholds, the redness object candidate will be retained. Otherwise, the object is eliminated (Hue Eliminated Image).

The last process is redness object marking using the Canny method. This process marks the redness objects obtained from the Hue Eliminated Image. First, the edge pixels of each redness object in Hue Eliminated Image are detected using the Canny method. In the Original Image, the intensity value of those edge pixels will be changed to red.

\section{RESULTS AND DISCUSSION}

All processes that have been designed in Fig. 1 were implemented into program code using MATLAB software. The first process is image resizing. The output of this process is the image that looks similar to the original image, but the size of the image is different. The maximum size, $500 \times 500$ pixels, is determined based on the training process that gives the best performance for this study. In addition, image size that exceeds 500x500 pixels will take a longer time for computation.

The HSV color space is used in the skin segmentation process because it can distinguish between brown, red, or other tones in the skin image. In addition, HSV is purest form of color based on wavelength that can truly describe the human colors. Images with non-black 
and non-white skin color use hue values and saturation for the segmentation processes [14]. This research only uses the hue and saturation layers according to the data set used in this study. The parameter values of HSV are according to [15].

K-Means clustering is a process to group the results of the HSV segmentation into three clusters. In the skin segmentation process, there are still background objects in the image that are categorized as skin, so this process is needed. This clustering separates skin, nonskin, and background objects. The system will use the intensity value as a reference to group each pixel. The result of K-Means clustering can be seen in Fig. 2(a)-(c). The cluster that has the highest number of members, Fig. 2(a), is chosen. The cluster that has the highest number of members is chosen because face skin is the largest area in the image. Unfortunately, Fig. 2(a) has many holes. To close those holes, a region filling algorithm is applied. The result of skin segmentation can be seen in Fig. 2(d). The face skin can be segmented except the eyebrow. In the redness detection, this is not an issue because this study looks for the redness object that has red color characteristics.

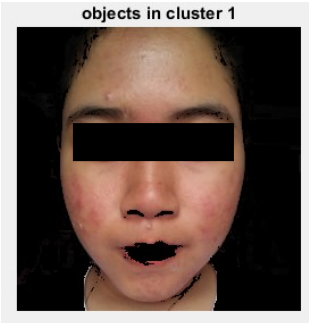

(a)

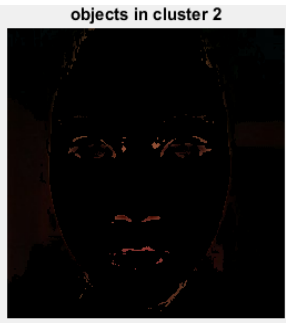

(b)

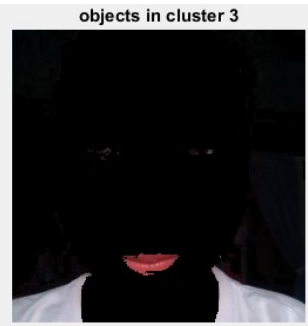

(c)

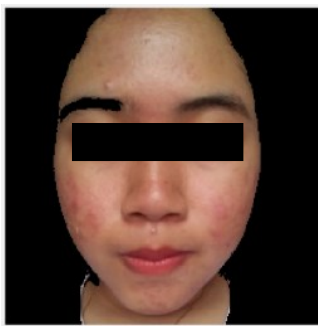

(d)

Fig. 2: K-Means Clustering Segmentation.

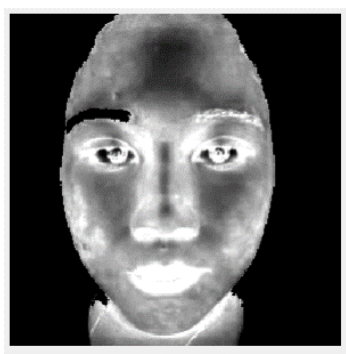

(a)

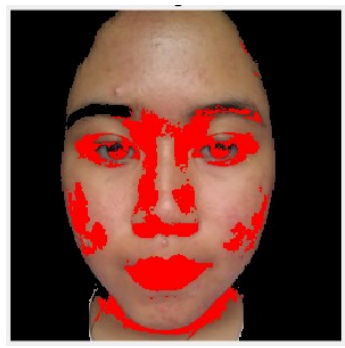

(b)

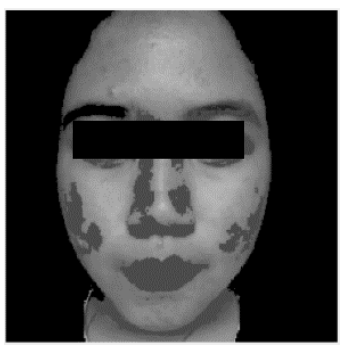

(c)

Fig. 3: Redness object detection (a) Redness method (b) Redness Pixel (c) Gaussian Filtering.

Next, the result of redness object detection with the Redness method can be seen in Fig. 3(a) and 3(b). This method identifies the redness pixel using dynamic parameters according to the RGB value of each pixel. It is different from using manual color segmentation which requires the researcher to search the redness range of each image. Gaussian Filtering is needed to eliminate scattered noise by smoothing the images. This filter can eliminate noise with results that look similar to the original image. Noise is eliminated without removing redness objects. The result of image improvement with Gaussian Filtering is shown in Fig. $3(\mathrm{c})$.

However, in Fig. 3(c) non-redness pixels are still marked, as in the eyes, nose, and lips. So, to eliminate non-redness pixels, another extraction is conducted. Non-redness objects eliminated based on pixel value in Gauss Image and Redness Image. Area, mean intensity 
RGB, and Hue mean intensity of each object are calculated. The results of those processes are shown in Fig. 4(a)-4(d), respectively.

The result of the previous elimination process is able to eliminate several non-redness objects in the lips. A threshold of 90 for area is selected according to the smallest area of redness objects in the training data. The non-redness objects that are eliminated are quite numerous, with only the large objects left in the nose and neck. When using RGB intensity, the system can eliminate non-redness object in the neck. While using Hue intensity can eliminate the non-redness objects in the nose.

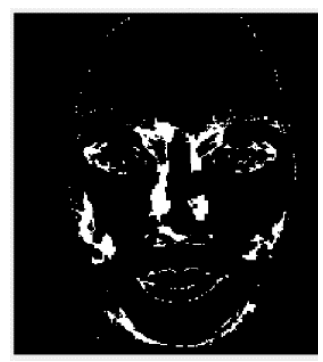

(a)

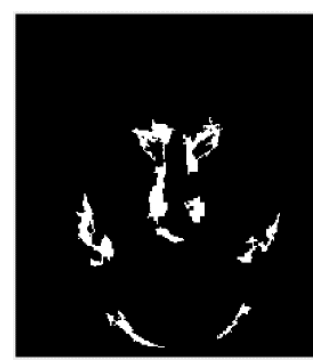

(b)

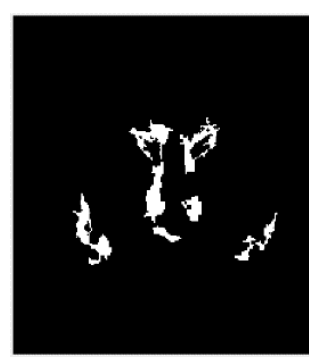

(c)

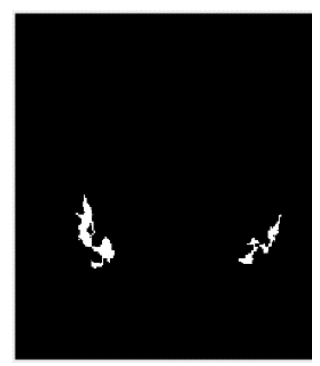

(d)

Fig. 4: Feature Extraction (a) by Index (b) by Area (a) by RGB color space (b) by Hue intensity.

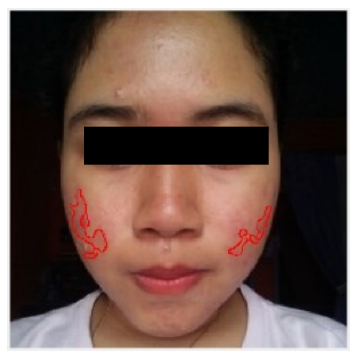

Fig. 5: Redness object Marking.

The marking process aims to make it easier for users to find the redness object location in face image. The result of marking process can be seen in Fig. 5. The system interface for this study is shown in Fig. 6. The interface of this system consists of three panels. The first panel has an "Insert Image" button and the third panel has a "See Result" button to see the detection results.

The algorithm is validated using a confusion matrix that evaluates 33 test images. The validation process compares the results given by system to the expert's diagnostic. The experts are a dermatologist from the Faculty of Medicine in Universitas Islam Indonesia and personnel of PT.AVO Innovation Technology. The validation results that compare to the dermatologist get low sensitivity value namely $54 \%$ but the specificity and accuracy values can achieve $99.1 \%$ and $96.2 \%$. The validation results that compare to PT.AVO Skin Innovation Technology personnel reach similar results. The sensitivity, specificity, and accuracy values are $67.4 \%, 99.1 \%$, and $97.7 \%$, respectively. 


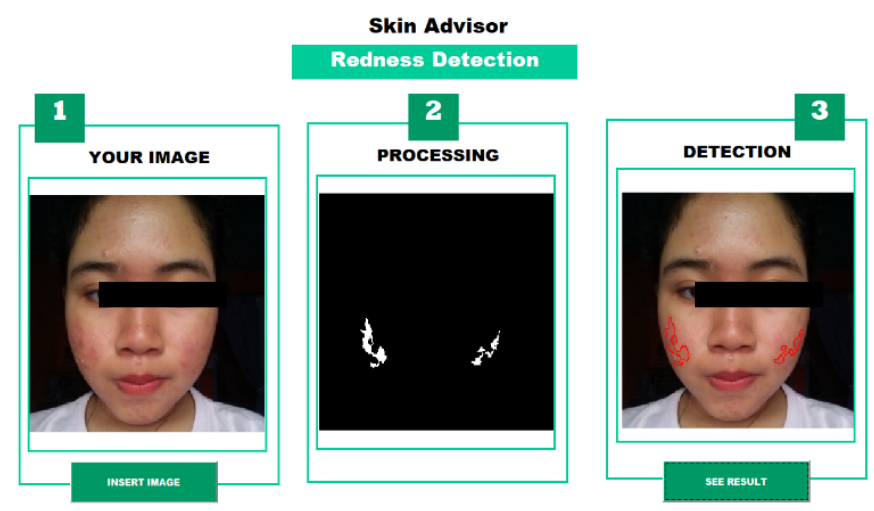

Fig. 6: Interface for Redness Object Detection.

Sensitivity that can only reach around $60 \%$ indicates that the detection of the redness object has not yet been optimal. To find the cause of detection failure, the researcher compared the results of the redness marking by the system and the assessment of the expert. In this study there are three causes of failure, namely poor image quality, uneven lighting, and overly wide range of redness color objects. The resolution of the image in Fig. 7(a) is only $250 \times 250$ pixels and the lighting is unevenly distributed. In the segmentation process, several parts of skin pixels are categorized into cluster backgrounds. It makes the redness objects unable to be detected in the following step. In Fig. 7(a) the redness objects are diagnosed by experts while in Fig. 7(b) the redness objects are detected by the system.

In Fig. 7(d) there are several redness objects that are not detected by the system, whereas they are diagnosed by experts in Fig. 7(c). On the other side, there are also some non-redness objects that were detected as redness objects by the system. Those redness objects cannot be selected by the system because of the range of mean intensity. Hue colors on the redness object are between 0.01 to 0.17 . Meanwhile the range of mean intensity of the Hue colors of non-redness objects are between 0.02 to 0.05 . So, there are non-redness objects detected as objects, namely eyebrows, lips, and neck. In addition, there are also undetectable redness objects, such as in the left cheekbone because it has a value of 0.4. However, if the Hue color range is increased, it can make the system detect non-redness parts as an object.

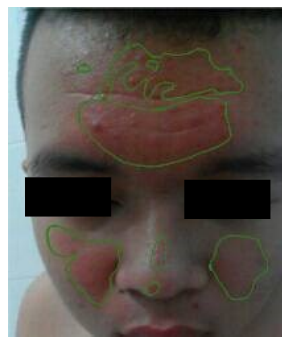

(a)

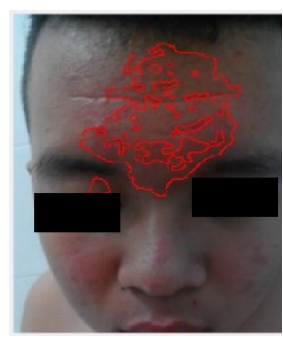

(b)

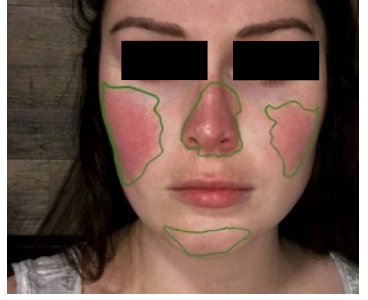

(c)

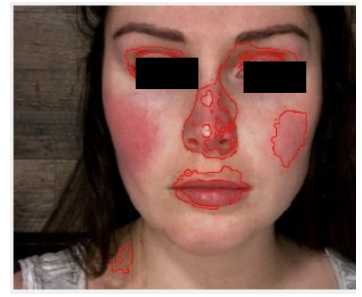

(d)

Fig. 7. Redness object detection; (a) by expert (b) by System (c) by expert (d) by System.

\section{CONCLUSION}

This paper tries to make a facial redness detection system that can analyze facial conditions, especially redness, through facial skin images. The system is expected to help patients for early detection of skin redness conditions to make it easier to select appropriate 
facial care products and health care. The redness detection process begins by detecting facial skin in facial images. Furthermore, the redness area will be identified on the facial skin object obtained in the previous process. The method used for detecting red objects on face skin for this research is the Redness method. The output of the Redness method will be optimized by feature selection based on area, mean intensity of RGB, and mean intensity of Hue Intensity. The validation value used is sensitivity, specificity, and accuracy based on experts, namely a dermatologist and PT.AVO Innovation Technology personnel. The results obtained based on the dermatologist is $54 \%, 99.1 \%$, and $96.2 \%$ for sensitivity, specificity, accuracy, respectively. Meanwhile, the results from PT.AVO personnel are $67.4 \%, 99.1 \%$, and $97.7 \%$, for sensitivity, specificity, accuracy, respectively. The cause of the sensitivity only reaching around $60 \%$ are poor image quality, uneven lighting, and an overly-wide range of colors for each object.

\section{ACKNOWLEDGEMENT}

The authors are grateful to the Informatics Department, Universitas Islam Indonesia for the financial support granted to cover the publication fee of this research article and to PT.AVO Innovation Technology personnel for image dataset support.

\section{REFERENCES}

[1] Weller H, Mann M, Hunter H. (2015) Cosmetic dermatology: Weller H, Mann M, Hunter H. Clinical dermatology. $5^{\text {th }}$ edition. Chichester, Wiley-Blackwell; pp. 323-333.

[2] Fernando E. (2015) Prototype Content Based Image Retrieval Untuk Deteksi Penyakit Kulit Dengan Metode Edge Detection (Studi Kasus : Klinik Penyakit Kulit RSU. Mataher JambiIndonesia) (Content Based Image Retrieval Prototype for Detection of Skin Diseases by Edge Detection Method (Case Study: Skin Disease Clinic, General Hospital, Mataher JambiIndonesia)). Jurnal IPTEKS Harapan, 2: 214-223.

[3] Herbin M, Venot A, Devaux J, Piette C. (1990). Colour quantitation through image processing in dermatology. IEEE transactions on medical imaging, 9(3):262-269.

[4] Sainthillier JM, Mac S, Humbert P. (2007) Assessment of rosacea by image processing and neural network. Expert Review of Dermatology, 2(3): 277-282.

https://doi.org/10.1586/17469872.2.3.277

[5] Ledoux A, Richard N, Capelle-Laizé AS, Fernandez-Maloigne C. (2015) Perceptual color hit-or-miss transform: application to dermatological image processing. Signal, Image and Video Processing, 9(5): 1081-1091.

[6] Gessert CE, Bamford JT. (2003) Measuring the severity of rosacea: a review. International journal of dermatology, 42(6): 444-448. https://doi.org/10.1046/j.1365-4362.2003.01780.x

[7] Novin IA, Aarabi P. (2014, October) Skin lens: Skin assessment video filters. In 2014 IEEE International Conference on Systems, Man, and Cybernetics (SMC); pp. 1033-1038. https://doi.org/10.1109/SMC.2014.6974049

[8] Franks AG. (1993) Cutaneous manifestations of disorders of the cardiovascular and pulmonary systems: Dermatology in general medicine. $4^{\text {th }}$ edition. New York, McGraw-Hill; pp. 2063-104.

[9] Fadhilah AN, Fatimah DDS, Damiri DJ. (2012) Perancangan Aplikasi Sistem Pakar Penyakit Kulit Pada Anak Dengan Metode Expert System Development Life Cycle (Designing Expert System Application for Skin Diseases in Children with Expert System Development Life Cycle Method). Jurnal Algoritma, 9(1): 112-118.

[10] Zaitoun NM, Aqel M. (2015) Survey on image segmentation techniques. Procedia Computer Science, 65: 797-806.

[11] Al-Najdawi N, Biltawi M, Tedmori S. (2015) Mammogram image visual enhancement, mass segmentation and classification. Applied Soft Computing, 35: 175-185. 
[12] Chavan A, Bendale D, Shimpi R, Vikhar P. (2016) Object detection and recognition in images. International Journal of Computing and Technology, 3(3):148-151.

[13] Owens DK, Sox HC. (2014) Biomedical decision making probabilistic clinical reasoning. In Biomedical Informatics, Springer, London; pp. 67-107.

[14] Shaik KB, Ganesan P, Kalist V, Sathish BS, Jenitha JMM. (2015) Comparative study of skin color detection and segmentation in $\mathrm{HSV}$ and $\mathrm{YCbCr}$ color space. Procedia Computer Science, 57: 41-48.

[15] Mujahidi, S. (2012) Aplikasi perhitungan jumlah orang dalam satu foto (Application for calculating the number of people in one photo). Thesis. Universitas Islam Indonesia, Department of Informatics. 